\title{
BUSINESS INCUBATORS IN SERBIA AND THEIR INTERACTION WITH ECONOMIC, SOCIAL AND SCIENTIFIC INSTITUTIONS
}

\author{
I. Zedi ${ }^{1}$, T. Atanassova-Kalaydzhieva ${ }^{2}$ \\ ${ }^{1}$ Faculty of Economics in Subotica, University of Novi Sad, Serbia \\ ${ }^{2}$ Faculty of Economics, Trakia University, Stara Zagora, Bulgaria
}

\begin{abstract}
The purpose of this study is to establish the role of business incubators and their partnership with other economic, state and scientific institutions in Serbia, based on a survey conducted with incubator managers. State institutions and research institutions, as well as universities, are the main partners of business incubators. This cooperation has become a cornerstone of modern Serbian business. To succeed, businesses need to bind to a number of other companies and businesses such as investors, research institutions, economic organizations, local authorities, economic development organizations, and others. The positive effects of creating cluster networks and business incubators are many. Such clustering creates tangible partnerships between start-ups and international companies that support and promote small and medium-sized businesses in Serbia.
\end{abstract}

Key words: incubator, business, customers, small and medium-sized enterprises, collaboration, institutions.

\section{INTRODUCTION}

Business incubators are organizations spread across many countries around the world. They are created to stimulate development and improve the conditions for the functioning of small and medium-sized enterprises (SMEs) in the country, to support entrepreneurs in achieving their business goals. They play an important role in providing knowledge and experience to start-up enterprises, successfully building, managing and growing them in market conditions. There are significant differences in the establishment and operation of business incubators in Western democracies and those in Central and Eastern Europe. (1)

The Republic of Serbia, as a transformative country from the Eastern bloc and started accession negotiations with the EU in early 2014, has quite specific features in setting up business incubators, establishing them, as well as in how they interact with various economic, state and scientific institutions.

In this regard, the purpose of this study is to identify and analyze the role of business incubators in the Republic of Serbia, the peculiarities of their establishment and the difficulties in functioning, as well as to provide guidance for successful development.

\section{FEATURES OF THE ESTABLISHMENT OF BUSINESS INCUBATORS IN THE REPUBLIC OF SERBIA}

The process of establishing business incubators in the country started in 2003. The first business incubator started in Niš in 2004 and in 2005 in Knjazevac - Figure 1. It is founded by Timok Club citizens' associations and is the first private business incubation initiative in the Republic of Serbia (2).

The establishment of business incubators in Serbia is heavily supported by the ENTRANSE Entrepreneurship Development Program, funded by the Government of the Kingdom of Norway. The program works in close cooperation with two state institutions, the first being the Agency for Development of Small and Medium-Sized Enterprises and the Ministry of Economy and Privatization of the Republic of Serbia.

As a result of the partnership between these institutions, a Business Incubator Support 
Center was established in 2006 within the SME Development Agency.

In 2006, the ENTRANSE Program also provided technical assistance to the Ministry of Economy and the Serbian SME Development Agency in the preparation of a Program for the
Development of Business Incubators and Clusters in the Republic of Serbia for a period of three years (2007-2010). The objective is to create at least 15 business incubators and to establish a National Association of Business Incubators in the Republic of Serbia.

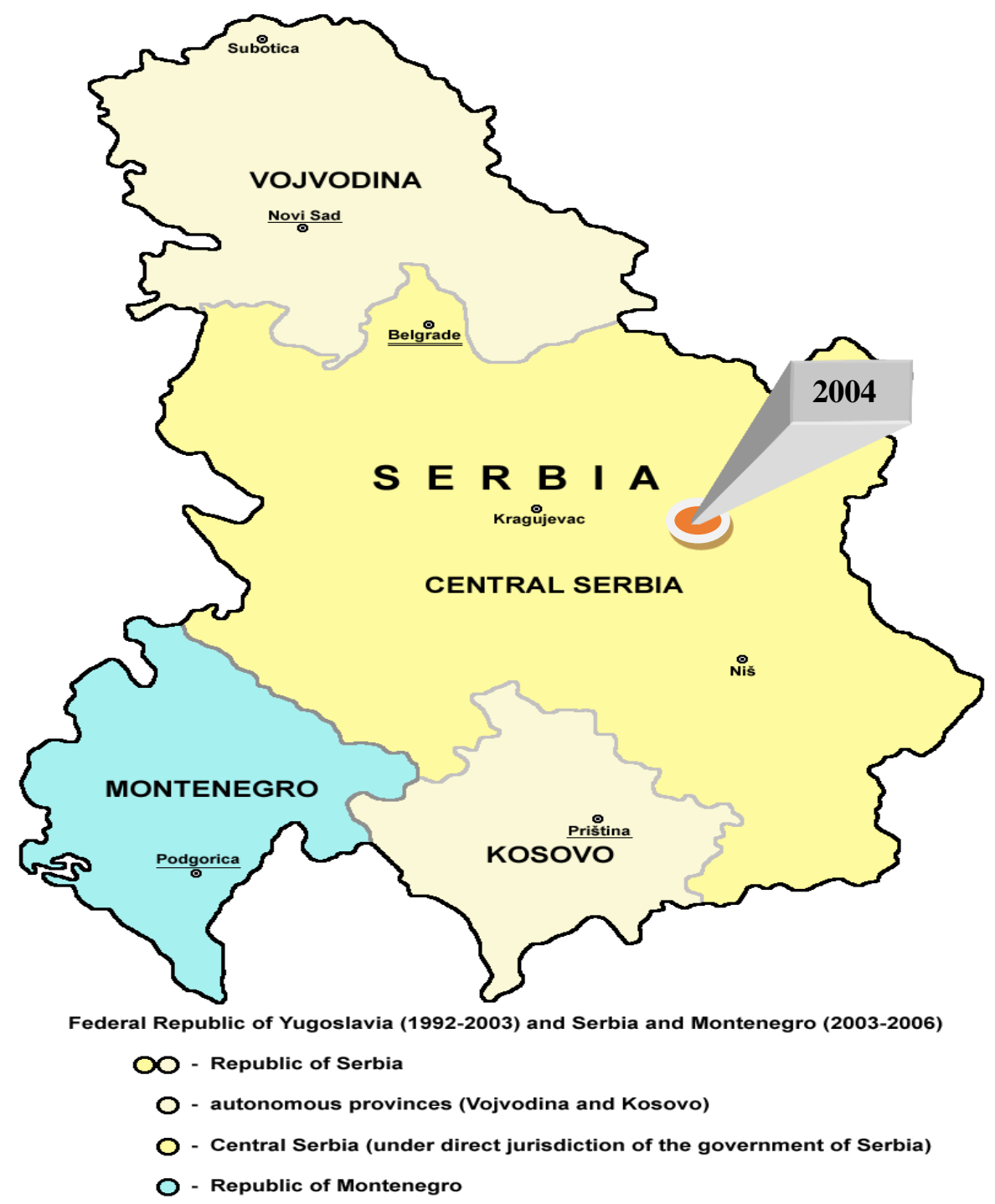

Figure 1. Administrative division of Serbia and location of the first business incubators

The Austrian Development Agency also supported the construction of a business incubator in Vojvodina, in cooperation with regional authorities. This is implemented and funded through the "Integrated Plan for the Autonomous Province of Vojvodina - Regional Development" program.

The United States Agency for International Development (USAID) is also assisting in the establishment and development of business incubators in Serbia. It finances the construction of the physical space and provides technical equipment to the incubators in
Krusevac, Zajecar, Prokuplje, Novi Sad and Kragujevac. $(3,4)$

By the end of 2011, 23 business incubators were already operating in Serbia. Most were established in the Vojvodina region in: Novi Sad, Subotica, Zrenjanin, Bački Petrovac, Pancevo, Subotica, Kanjiža and Beochin. The greater number of incubators in Vojvodina than in other parts of Serbia is the result of the assistance of the programs of the Austrian Development Agency and the targeted investments of the Vojvodina government.

In Eastern and Southern Serbia, 7 business incubators have been established in: Nis, 
Vranje, Zajecar, Bor, Knjazevac, Prokuplje and Medvedja. There are also initiatives in the area to create 2 new incubators in Maidanpek and Kladovo.

Six business incubators have been identified in Sumadija and Western Serbia, of which 4 are already operational and 2 are newly constructed. They are located in Kragujevac, Raka, Uzice, Valevo and Kraljevo. There are 2 business incubators operating in Belgrade in the municipalities of Zvezdara and Rakovica (2).

\section{PROBLEMS WITH THE FUNCTIONING OF BUSINESS INCUBATORS IN THE REPUBLIC OF SERBIA}

Serbia's National Regional Development Agency, through a questionnaire sent to 12 incubators, is conducting a study. The obtained data show that the established business incubators have as their main objective the restructuring of the employed workforce in the privatized large enterprises. Incubators are established as limited liability companies, and co-founders (partners) are local authorities, businesses, NGOs, etc. Many business incubators have a business plan in place worked out that outlines their vision, mission, and strategic goals. (5)

The type of business incubators in Serbia is predetermined by the area where they are located. When the incubator is found in factory premises, its activity is associated with production, such as in the woodworking and mechanical engineering industries. Some of these incubators also carry out other nonproductive activities.

A special category of business incubators are those built entirely in newly built sites. These incubators are mainly manufacturing activities, although there are tenants involved in the service sector.

Another type of business incubator is those created on the territory of public or private sites and commercial buildings adapted to their needs. In this kind of service activities are performed in the field of information technology, with a wide range of business services, such as accounting, legal, employment, mediation, design, training, media and others.

The "double" incubator is started under a virtual incubation process, such as in Belgrade and Novi Sad. They are created as virtual incubators, operating within the Faculty of Engineering at the University of Novi Sad. Another similar business incubator is in Kragujevac, funded by EU programs for the construction of a virtual thermostat $(2,6)$.

Serbian entrepreneurs and Serbian microenterprises occupy a major place in the business incubator business, but foreign companies also have offices in many of them. Most business incubators have their own website that contains information about their activities and lists of participants. Despite significant investments and subsidized prices for modern equipment, their construction is not fully completed and $35 \%$ to $90 \%$ of their capacity is used. $(2,7)$

Researches and analyses of business incubators in Serbia, especially in the first years of their establishment, found serious gaps in their work and their expediency. Their goal is to develop entrepreneurship, micro and small enterprises in the country, but under poor management, they are not able to achieve their goals, and this calls into question their existence.

Despite good technical equipment, most incubators in Serbia are financially unsustainable, as the finances they receive are not enough to cover even basic operating costs. The subsidies provided by the state or regional budget are strongly curtailed, especially in times of economic crisis (2011-2014). As a result, almost all incubators in Serbia have a problem with solvency, which results in irregular payments and salaries of their employees. Most of the incubators are set up within the framework of a specific project donor, and after its termination stops financial support, and without operating support grants they cannot function.

In addition to the problems mentioned, there is another.

It is still difficult to attract successful companies, with very few exceptions to existing incubators in Belgrade, Novi Sad and Nis.

A disadvantage in the activity of part of the business incubators is the provision of a limited range of services, such as consulting, training, business plan development, administrative assistance. Few of them provide specialized business services, while most outsource to organizations, so they only play 
an intermediary role. Business incubators are difficult to adapt to market changes. Most incubators are unable to support the activities of innovative SMEs in need. Most business incubators in Serbia are not prepared to respond to innovative management consulting, IP consulting, trade mediation and penetration, to help develop investment projects, to orientate companies in need of access to capital. (6)

There is also a significant lack of cooperation of business incubators with universities and research institutions in order to acquire new knowledge and achieve higher economic results. Only a few incubators in the country operate effectively and can provide a wide network of activities and support businesses on a scientific basis, as a result of cooperation with universities and faculties in the country and non-governmental organizations. (4)

Despite the existing problems with the establishment and functioning of business incubators in the Republic of Serbia, it can be argued that they will continue to play an important role in the development of entrepreneurship in the country, but targeted measures are needed.

\section{GUIDELINES FOR OVERCOMING PROBLEMS AND SUCCESSFUL DEVELOPMENT OF BUSINESS INCUBATORS IN THE REPUBLIC OF SERBIA}

The study identified the need to diversify the services provided by business incubators in Serbia and improve their quality. New opportunities must be sought to facilitate connection with economic operators in the country. For this purpose, it is necessary to create a special network for closer contacts with representatives of the business centers in the individual parts of the country, especially for those who have limited access to other institutions and agencies that support the development of entrepreneurship. An important prerequisite is that the incubation activities be linked to national and regional development strategies. Incubators are created inadvertently, above all, to promote local economic development and to meet the potential and needs of businesses in a region. (8)

Efforts should also be directed to the development of skills for the development of incubator management skills for higher quality of services, especially for the specialized ones.
The study shows that this is the only way to identify and develop appropriate contacts with potential business partners, organizations and institutions that can be involved in the further development of business incubators. This will establish contacts with representatives of different sectors of the economy, strengthen cooperation with clusters, agencies and regional development organizations.

The main factor for ensuring the financial sustainability of the established incubation infrastructure is the building of skills for incubating business activities. These skills did not exist before, and the newly developed incubation infrastructure could not be established without them.

In order to stimulate cooperation between business incubators and businesses, especially in smaller municipalities in the country, premises for the construction of their offices should be provided by municipal administrations. In parallel, to inform and advertise to the local community the activities and the provided business services, professional consultations and trainings. This will achieve synergy in the actions of all actors in local economic development. In most cases, it is difficult to find an incubator because there is no information or ads that would in any way indicate its incubation in the region. Given that they provide services to local businesses, it is necessary, as soon as possible after their location in a new territory, to improve their visibility, both for the target groups and for the local community as a whole. (9)

In order to analyze, evaluate and compare the performance of different business incubators at national level, as well as to take measures for their development, a uniform system of criteria and norms should be created. In this regard, a national standard for business incubators should be established as organizations that play a crucial role in supporting small and mediumsized enterprises.

The introduction of uniform national standards will help to measure the effects of business incubators on SMEs and thus compare their effectiveness.

It is necessary to intensify the cooperation between scientific institutions and business incubators, which will help to improve the quality of services offered, to develop innovative solutions, to better serve SMEs and effectively support their businesses. It is 
important for the incubator and the management team to have the skills, be prepared to provide rational solutions, transfer knowledge to solve the problems of the newly built business structures.

Business incubators in Serbia should also benefit from the experience and support of the European Network of Business and Innovation Centers (EBN), which has also developed a specific "Guide to Regional Innovation Strategies (RIS)". It has development guidelines based on the experience of generations of regional innovation strategies to design and support business projects and networks. Some experience in this area can also be provided by one of the EU's Regions for Economic Change initiatives, which aims to promote the exchange of good practices between European regions as a means of boosting innovation. (9)

It is advisable to take into account the new orientation of the Enterprise Europe Network (Enterprise Europe Network, EEN, 2015 2021), which participates in the dissemination of good practices at European level among regional SME support services, in point. hours business incubators. Partners in the Enterprise Europe network collaborate with other European networks to carry out activities and to offer guidance for successful development.

\section{CONCLUSION}

Investments in business incubators are more a growth factor than a driving force. The establishment of business incubators in Serbia, as in other countries in transition to a market economy, provides opportunities for start-up SMEs to benefit from different types of assistance. Business incubators alone cannot generate economic growth, but their services contribute to improving the economic environment in the areas where they are built. They assist the business in meeting the new requirements of the market environment, developing a business plan and finding profitable sources of financing, enhancing the knowledge and skills of those who create and manage their own businesses, inter-company cooperation and contacts with local and national institutions level, as well as in other areas of business.

The successful future development of business incubators in Serbia necessitates the need for a smart specialization strategy that focuses on the characteristics of entrepreneurship in the region with the active involvement of businesses. In this way, the business needs are combined with the development activities, they create preconditions for the quality and efficiency of their activities.

\section{REFERENCES}

1. Lesáková, L., The Role of Business Incubators. Act Polytechnic Hungarian, Volume 9., Issue 3., pp. 85-95., 2012.

2. Mijačić, D., Analysis of Business Support Infrastructure in the Republic of Serbia. National Agency for Regional Development, Beograd., pp. 11-13., 2011.

3. Mandić, V., Strategic Development Plan for Business Incubators and Science and Technology Parks in Western Balkan Region. University of Kragujevac, WBCInno project., 2014.

4. Hutchinson, J. et al., Youth Entrepreneurship in Serbia: Constraints and Opportunities. United States Agency for International Development (USAID)., 2012.

5. Markovic, N., J. Milinkovic, T. Serdar., Business Incubators as Instruments of Support to the Regional Cooperation. Annals of the Oradea University, Fascicle of Management and Technological Engineering., Issue 2., pp. 140-146., 2013.

6. Zedi, I., The Network of Incubators and Clusters in the Republic of Serbia: Improving the Competitiveness of SMES Through Institutional Support. Economic Studies, Volume 4, pp. 137-158., 2014.

7. Research for Innovation. Strategy on Scientific and Technological Development of the Republic of Serbia for the period 2016 - 2020. Ministry of Education, Science and Technological Development of Republic of Serbia., 2016.

8. Tengeh R.K., P. Choto., The relevance and challenges of business incubators that support survivalist entrepreneurs. Investment Management and Financial Innovations, Volume 12, Issue 2, pp.150161., 2015.

9. Special report of the European Court of Auditors: "Has the ERDF successfully supported the development of business incubators?", Issue 7., Luxembourg., pp. 79-85., 2014. 